\title{
Vitamins C, D and Zinc: Synergistic Roles in Immune Function and Infections
}

\author{
Silvia Maggini ${ }^{1^{*}}$, Paola Maldonado ${ }^{2}$, Paula Cardim ${ }^{3}$, Carlos Fernandez Newball ${ }^{4}$ and Emanuel R Sota Latino ${ }^{5}$ \\ ${ }^{1}$ Bayer Consumer Care AG, Peter Merian-Strasse 84, P.O. Box, 4002 Basel, Switzerland \\ ${ }^{2}$ Bayer de Mexico S.A. de C.V., M. Cervantes Saavedra 259, Col. Ampliación Granada, 11520, Mexico DF, Mexico \\ ${ }^{3}$ Bayer Consumer Health, Rua Domingos Jorge, 1100 Cep 04779900, Socorro, São Paulo-SP, Brazil \\ ${ }^{4}$ Bayer S.A., Carrera 58 No. 10, 76 Bogotá, Colombia \\ ${ }^{5}$ Bayer S.A. Ricardo Gutierrez 3652, B1605EHD, Munro, Buenos Aires, Argentina
}

*Corresponding author: Maggini S, Bayer Consumer Care AG, Peter Merian-Strasse 84, P.O. Box, 4002 Basel, Switzerland, Tel: +41 58 272 7516; E-mail: silvia.maggini@bayer.com

Received date: August 16, 2017; Accepted date: August 25, 2017; Published date: September 04, 2017

Copyright: (C) 2017 Maggini S. This is an open-access article distributed under the terms of the Creative Commons Attribution License, which permits unrestricted use, distribution, and reproduction in any medium, provided the original author and source are credited.

\begin{abstract}
The immune system is a complex and sophisticated network of specialized tissues, organs, cells, proteins, and chemicals which has evolved in order to protect the host from a range of dangerous agents such as bacteria, virus, fungi, and parasites. There is a close relationship between nutritional status and immune function. Hence, immunocompetence can be regarded as a measure of adequate nutrition. Inter-individual variations in many immune functions exist within the normal healthy population and are due to age, genetics, gender, ethnic background, socioeconomic situation, diet, stress, habitual levels of exercise, alcohol consumption, smoking habits, etc. In addition, seasonal and temperature changes as well as being in crowded spaces (e.g., while commuting in public means of transportation, or working in open space offices) pose an additional burden on the immune system.
\end{abstract}

Among the essential micronutrients required to support a normal immune function, vitamin $C$, vitamin $D$ and the mineral zinc play a central role. Through their complementary and synergistic effects, they support components of both innate and adaptive immunity which comprise epithelial barriers, cellular defense and antibodies constituting the three main lines of immune defense. Furthermore, vitamin C, D and zinc are actively used by cells of the immune system engaged in fighting infections like upper respiratory tract infections and a state of micronutrient deficiency can arise during severe infections.

Here we review the literature on the immune supportive properties of vitamins C, D and zinc and the impact of their supplementation in reducing the incidence or ameliorating symptoms of upper respiratory tract infections, which are among the most common infections in humans. Finally, we discuss their relevance in situations known to challenge the immune system such as exposure to temperature changes, to pollutants, or being in crowded spaces which serve as mixers where pathogens can stay suspended and transfer from host to host thereby increasing the risk of spreading infectious diseases because of close contact and long exposure.

Keywords: Vitamins C, D; Trace elements zinc; Effects on immune response; Nutrient deficiency; Supplementation

\section{Introduction}

Every second of our lives, during day and night, immune defenses are constantly protecting the human body against attack and invasion by external pathogens such as fungi, bacteria, viruses but also against internal threats such as humoral proliferation. Over millions of years the human immune system (i.e., our defense arsenal) has co-evolved to meet various attackers and now ranges from simple physical barriers (skin, mucosa) to sophisticated cells as well as biological, chemical and nuclear weapons (antibodies, cytokines and free radicals respectively). Despite this complexity, the immune system can be described for educational purposes as consisting of three main layers, i.e., epithelial barriers (e.g., skin, mucosa); cellular defenses and humoral responses such as antibody production [1-3].
Inter-individual variations in many immune functions exist within the normal healthy population and are due to genetics, age, gender, ethnic background, smoking habits, socio-economic situation [4], habitual levels of exercise, alcohol consumption, diet, stage in the female menstrual cycle, stress, etc. [5]. Immune cells, like other cell types, need to be fed: they require adequate supply of energy, macronutrients and micronutrients serving as cofactors in the development, maintenance and expression of the immune response. The contribution of the diet to immune function has become widely appreciated and the influence of various dietary components on specific aspects of immune function has been extensively reviewed $[2,6,7]$. It is now generally recognized that the nutritional status of a person modulates his or her immunity and in fact, immunocompetence can be regarded as a measure of adequate nutrition. In addition to macronutrients including amino acids, fatty acids, nucleotides, gangliosides or other dietary components such as probiotics, also an adequate and regular supply of essential vitamins and minerals (including trace elements) is required to maintain proper 
immune function and can hence contribute to disease prevention and overall health.

When it comes to micronutrients, especially vitamins C and D as well as zinc play key roles in immune function. Vitamin $\mathrm{C}$ is a cofactor for several enzymes involved in the biosynthesis of collagen, carnitine, and neurotransmitters; it's a water-soluble antioxidant and enhances gastrointestinal absorption of dietary non-heme iron. Marginal deficiency results in fatigue, lack of well-being, poor concentration whereas severe deficiency will cause weakening of collagenous structures, causing tooth loss, joint pains, bone and connective tissue disorders (e.g., impaired bone growth and disturbed ossification), poor wound healing and a compromised overall immunity $[2,8]$. Vitamin D (calciferol) is a fat-soluble vitamin. The classical biological function of vitamin $\mathrm{D}$ is mediated through its metabolites and is to maintain calcium and phosphorous homeostasis by regulating the intestinal absorption of these nutrients and thus being essential for bone formation and resorption. Evidence showing that activated macrophages are also able to produce the vitamin $\mathrm{D}$ metabolite 1,25 dihydroxy vitamin $\mathrm{D}(1,25(\mathrm{OH}) 2 \mathrm{D})$ and the presence of vitamin $\mathrm{D}$ receptors (VDR) on immune system cells, indicate important roles for $1,25-(\mathrm{OH}) 2 \mathrm{D}$ in modulating immune response, immune cell differentiation, and cell proliferation. Vitamin D3 is the naturally occurring form of vitamin $\mathrm{D}$ in humans. The dietary absence of vitamin $\mathrm{D}$ and/or a lack of adequate exposure to sunlight result in vitamin $\mathrm{D}$ deficiency characterized by inadequate mineralization or demineralization of the skeleton [9]. Zinc is required in numerous transcription factors and enzymes, it plays a central role in cellular differentiation and proliferation and its deficiency causes growth retardation, skin changes, impaired immune response, increased susceptibility to infections, delayed wound healing, abnormal dark adaptation, delayed sexual maturation, and impaired fertility $[10,11]$.

While multiple factors determine whether an individual will become sick or not, the immune system remains the first line of defense against all external pathogens and noxious insults. It is therefore of utmost importance to adequately feed the immune system by providing those micronutrients needed to ensure proper functioning. This article will illustrate how vitamins C, D and the trace element zinc, work in synergy to support the three main layers of the immune system such as epithelial barriers, cellular response and antibody production. It will briefly review their roles in upper respiratory tract infections and their relevance in situations known to challenge the immune system such as exposure to temperature changes, to pollutants, or being in crowded spaces.

\section{Immune Function and Upper Respiratory Tract Infections}

Vitamin C: The immune-enhancing roles of vitamin $\mathrm{C}$ are well established [12,13]. Vitamin $C$ regulates the immune system because of its antioxidant properties and its role in collagen synthesis required for stabilization of epithelial barriers. Additionally, it impacts phagocytic function and has an immunostimulant effect on lymphocyte cells [14]. Vitamin C is highly concentrated in leukocytes and is used rapidly during infection $[15,16]$. In fact, it has been defined as a stimulant of leukocyte functions, especially of neutrophil and monocyte movement $[14,17]$. Recently, neutrophil motility has been proposed as a possible marker of vitamin $\mathrm{C}$ requirements underlying the intimate connection between vitamin $\mathrm{C}$ and immunity [18].
High vitamin C levels in neutrophils are necessary to counteract the extremely high levels of oxidative stress to which they are exposed following Reactive Oxygen Species (ROS) production $[12,17,19]$. ROS are generated during the respiratory burst to kill pathogens and are elevated in the inflammatory response. The oxidant-antioxidant balance is an important determinant of immune function and immune cells are particularly sensitive to changes in this balance because of the higher percentage of polyunsaturated fatty acids in their plasma membranes [20]. Oxidative damage can lead to a loss of membrane integrity, altered membrane fluidity and result in alterations in the transmission of signals both within and between different immune cells [21]

Large doses of vitamin C are able to markedly lower blood histamine levels and this reduction was inversely related to leukocyte chemotaxis [22,23]. Vitamin C stimulated interferon production in vitro when incubated with cultured mouse cells and in vivo when administered to mice [24]. Some evidence is available suggesting that ascorbic acid may have antiviral activity in humans [25-27]. Vitamin C deficiency is associated with a decreased resistance to disease, while high supplemental intakes can stimulate phagocytic and Tlymphocytic activities $[28,29]$. Finally, vitamin C may play a significant role in the regulation of the inflammatory response $[30,31]$.

Based on its immune-stimulating properties [15], vitamin C was postulated to be effective in ameliorating symptoms of upper respiratory tract infections, especially the common cold. Further, plasma and leukocyte vitamin $C$ concentrations fall rapidly with the onset of the infection and return to normal with the amelioration of the symptoms suggesting that vitamin $\mathrm{C}$ could be beneficial for the recovery process [32]. Indeed, a review of the large numbers of studies on a potential effect of vitamin $\mathrm{C}$ on the common cold and respiratory infections concluded that administration of $>1 \mathrm{~g} /$ day had a small but not consistent effect on the incidence of common colds, but consistently supported a moderate benefit on duration and severity of symptoms which may also be of economic advantage [33].

More recently, the Cochrane Library review on vitamin C and the common cold [34] concluded that regular supplementation with vitamin C ( 0.25 to 2 grams/day) did not reduce the occurrence of the common cold in the general population, but it did reduce it in individuals undergoing heavy physical stress, such as marathon runners, skiers, soldiers in subarctic conditions, and individuals with marginal vitamin C status. Prophylactic supplementation with vitamin $\mathrm{C}$ reduced the duration of the common cold in both children (14\% reduction) and adults ( $8 \%$ reduction). The severity of colds was also reduced by regular vitamin $\mathrm{C}$ administration. However, this was not seen in the few therapeutic trials carried out so far. Nevertheless, the authors concluded that given the consistent effect of vitamin $\mathrm{C}$ on the duration and severity of colds in the regular supplementation studies, and the low cost and safety, it may be worthwhile for common cold patients to test on an individual basis whether therapeutic vitamin $\mathrm{C}$ is beneficial for them [34]. Finally, the relation of the vitamin $\mathrm{C}$ dose to benefit needs further exploration and it is important to note that none of the studies analyzed in the Cochrane reviews took into account subjects' dietary intake or status of vitamin C.

In this context, it is important to mention a recent randomized, double-blind trial study showing that daily supplements of vitamin $\mathrm{C}$ both boosted activity levels and reduced incidence of common cold in young males pre-selected based on their vitamin C levels. The study included subjects with adequate-to-low vitamin $\mathrm{C}$ status $<45 \mu \mathrm{mol} / \mathrm{L}$ (i.e., marginal deficiency) who completed validated questionnaires 
assessing upper respiratory infections and exercise / physical activity respectively. Following intake of $1000 \mathrm{mg}$ vitamin $\mathrm{C}$, the physical activity score rose by $39.6 \%$ versus placebo. During the eight-week trial, the number of participants reporting cold indicated a $55 \%$ risk reduction for vitamin $\mathrm{C}$ versus placebo. Furthermore, cold duration was reduced by $59 \%$ in the vitamin $\mathrm{C}$ versus the placebo group. This study therefore confirmed the ability of vitamin $\mathrm{C}$ to ameliorate cold symptoms but showed that in terms of cold prevention, vitamin $\mathrm{C}$ is efficacious in subjects with sub-optimal levels of this vitamin. In these individuals the immune benefits go hand in hand with improved physical activity levels [35].

A comprehensive overview of vitamin $\mathrm{C}$ and infections has been recently published by Hemilä [8] who carefully evaluated the totality of the vitamin $\mathrm{C}$ literature including next to new publications also older papers as well as experimental data. From a large series of animal studies Hemilä concludes that vitamin $\mathrm{C}$ plays a role in preventing, shortening and alleviating diverse infections beyond cold and respiratory tract infections. According to the author, it seems evident that vitamin $\mathrm{C}$ has similar effects in humans. For example, five controlled trials found significant effects of vitamin $\mathrm{C}$ against pneumonia and preliminary evidence is available that vitamin $C$ may have effects also on other infections.

Vitamin D: Initial evidence supporting an immunostimulant role for vitamin $\mathrm{D}$ came from early reports about the use of cod liver oil in the treatment of tuberculosis. In the meantime, a number of reviews have shown that vitamin $\mathrm{D}$ and especially $1,25(\mathrm{OH}) 2 \mathrm{D}$ are potent immunomodulators $[9,36,37] .1,25(\mathrm{OH}) 2 \mathrm{D}$ is required to enhance the antimicrobial effects of immune cells such as macrophages and monocytes, needed to fight pathogens such as Mycobacterium tuberculosis. The effects of vitamin D are multiple and include enhancement of chemotaxis and phagocytic capabilities of innate immune cells along with the activation of the transcription of antimicrobial peptides (e.g., defensin $\beta 2$ and cathelicidin) achieved by the complex of $1,25(\mathrm{OH}) 2 \mathrm{D}, \mathrm{VDR}$, and retinoid $\mathrm{X}$ receptor [38]. In response to infections there is an upregulation of human cathelicidin (hCAP18) (cleaved from LL-37) which results in a destabilization of microbial membranes thereby acting against bacteria, viruses and fungi and helping fight infections $[39,40]$.

Besides fighting directly against microbes, cells of the innate immune system such as Dendritic Cells (DCs), are subject to the immune modulatory effects of vitamin $\mathrm{D}$. Innate antgen presenting cells (APC) trigger the initiation of the adaptive immune response by presenting antigens to $\mathrm{T}$ cells and $\mathrm{B}$ cells and influence their activity by immunogenic or tolerogenic signals such as cytokines [41,42]. Again, it's via cytokine modulation (such as IL-2, IL-6, IL-10, IL-12, IL-17) that $1,25(\mathrm{OH}) 2 \mathrm{D}$ can modify both the function and morphology of DC to induce a more tolerogenic state which in turn results into an overall induction of regulatory $\mathrm{T}$ cells important for controlling overall immune responses and the development of autoreactivity [43].

When it comes to adaptive immunity, both $\mathrm{T}$ and $\mathrm{B}$ cells express the nuclear VDR as well as vitamin D-activating enzymes [44]. Particularly, VDR expression by these cells increases from very low in resting conditions to high levels upon activation and proliferation, enabling regulation of up to 500 vitamin D responsive genes [45-47].

In $\mathrm{B}$ cells, $1,25(\mathrm{OH}) 2 \mathrm{D}$ inhibits differentiation, proliferation, initiation of apoptosis and decreases immunoglobulin production via mediation of $\mathrm{T}$ helper (Th) cells [45]. In addition, 1,25(OH)2D has direct effects of on $\mathrm{B}$ cell homoeostasis, encompassing inhibition of memory- and plasma-cell generation, promotion of apoptosis of antibody-producing B cells [47]. This control on B cell activation and proliferation is of clinical importance in autoimmune diseases where $\mathrm{B}$ cells producing autoreactive antibodies play a major role in the pathophysiology of autoimmune diseases [37].

$\mathrm{T}$ cells are also an important target for the immunomodulatory effects of vitamin D. Again, both direct and indirect mechanisms allow vitamin $\mathrm{D}$ to influence $\mathrm{T}$ cell function. The direct effects include: intracrine conversion of 25-hydroxy vitamin $\mathrm{D}(25(\mathrm{OH}) \mathrm{D})$ to $1,25(\mathrm{OH}) 2 \mathrm{D}$ by $\mathrm{T}$ cells, and paracrine effects of $1,25(\mathrm{OH}) 2 \mathrm{D}$ on $\mathrm{T}$ cells following conversion of $25(\mathrm{OH}) \mathrm{D}$ to $1,25(\mathrm{OH}) 2 \mathrm{D}$ by monocytes and/or DC. The indirect effects on antigen presentation to T cells are mediated via localized APC affected by $1,25(\mathrm{OH}) 2 \mathrm{D}$ [37]. Vitamin D exposure leads overall to a shift from a proinflammatory to a more tolerogenic immune status, including impacting on $\mathrm{T}$ cell subtypes. For example, 1,25(OH)2D suppresses $\mathrm{T}$ helper (Th) cell proliferation, differentiation and modulates their cytokine production [48].

As mentioned previously, $1,25(\mathrm{OH}) 2 \mathrm{D}$ stimulates the expression of anti-microbial peptides, synthesized in neutrophils, monocytes, Natural Killer (NK) cells but also in epithelial cells lining the respiratory tract where they are crucial in protecting the lung from infection [38,49-51]. One of the reasons why influenza occurs in the winter season in tepid climates has long thought to be linked to the skin inability to synthesize sufficient amounts of vitamin D thereby promoting and enhancing the infectivity of the influenza virus [52]. Indeed, vitamin D status has an effect on the ability of the host to fight infections as shown by many observational studies where low serum 25-OHD levels were associated with an increased risk of respiratory infections in adults, as well as in risk groups such as elderly, children and infants [10,53-55].

So far not all interventional trials have been able to confirm benefits of vitamin D supplementation on incidence and severity of upper respiratory tract infections e.g., [56]. However, a number of systematic reviews and meta-analyses concluded positively on the benefits of vitamin D supplementation in this area. In 2009 Yamshchikov et al. [57] conducted a systematic review on vitamin D and its use for treatment and prevention of infectious diseases. According to this review the strongest evidence for the effectiveness of vitamin $\mathrm{D}$ in prevention or treatment of infectious diseases was for the reduction of risk of acute respiratory illness and influenza. In 2012, Charan et al. [58] evaluated clinical trials reporting as an outcome events of respiratory tract infections. They found that events of respiratory tract infections were significantly lower in vitamin $\mathrm{D}$ group as compared to control group $(\mathrm{OR}=0.582 \quad(0.417-0.812) \quad \mathrm{P}=0.001)$. The authors concluded that vitamin $\mathrm{D}$ supplementation decreased the events related to respiratory tract infections. Bergman et al. [59] included 11 placebo-controlled studies of over 5'500 patients in their 2013 metaanalysis. They found that overall, vitamin $\mathrm{D}$ showed a protective effect against respiratory tract infections (OR, $0.64 ; 95 \% \mathrm{CI}, 0.49$ to 0.84 ). They also reported significant heterogeneity among studies but found that the protective effect was larger in studies using once-daily dosing compared to bolus doses $(\mathrm{OR}=0.51$ vs $\mathrm{OR}=0.86, \mathrm{p}=0.01)$.

Finally, a systematic review and meta-analysis of individual participant data from randomized controlled studies was published in 2016 [60] and identified 25 eligible trials with a total of 11'321 participants (aged 0 to 95 years). Overall, vitamin D supplementation reduced the risk of acute respiratory tract infection among all participants by $12 \%$. In subgroup analysis, protective effects were seen in those receiving daily or weekly vitamin $\mathrm{D}$ without additional bolus 
doses. Among those receiving daily or weekly vitamin $\mathrm{D}$, protective effects were stronger in those with baseline $25(\mathrm{OH}) \mathrm{D}$ levels $<25$ $\mathrm{nmol} / \mathrm{L}$ than in those with baseline $25(\mathrm{OH}) \mathrm{D}$ levels $\geq 25 \mathrm{nmol} / \mathrm{L}$. The authors concluded that vitamin D supplementation was safe and it protected against acute respiratory tract infection overall. Especially subjects who were vitamin $\mathrm{D}$ deficient and those receiving regular supplementation experienced the strongest benefit. The most common respiratory tract infection is the common cold, but others include bronchitis, pneumonia, and infections of the sinuses or ears. At least $70 \%$ of the population gets one or more respiratory infection in any given year [60].

Zinc: The immune-related functions of zinc have been reviewed recently [61-63]. Zinc is considered key for optimal functioning of both innate and acquired immunity and impaired immune functions due to inadequate zinc status may be the most common cause of secondary immunodeficiency in humans [64]. Zinc deficiency impairs cellular mediators of innate immunity such as phagocytosis of macrophages and neutrophils, NK cell activity, generation of the oxidative burst and complement activity [65-69]. Deficiency further causes thymus involution [70,71] and zinc is required for the activity of thymulin [72], a hormone involved in $\mathrm{T}$ cell differentiation and enhancement of $\mathrm{T}$ and NK cell actions [73]. Zinc deficiency further depresses lymphocyte proliferation, Th1 cytokines production (IL-2 and interferon- $\gamma$ ), and leads to a Th1/Th2 imbalance [74-76], Delayed Type Hypersensitivity (DTH) skin responses and antibody response to T-cell dependent antigens. Zinc homeostasis influences development and function of immune cells (particularly $\mathrm{T}$ cells) $[66,75,76]$ activity of stress-related and antioxidant proteins and helps to maintain genomic integrity and stability. In addition to its effects on cellmediated immunity, zinc is also an anti-inflammatory and antioxidant agent $[63,77]$.

Among the latest developments in zinc biochemistry is zinc's molecular role as a second messenger in immune cells [61]. A growing number of signaling pathways were discovered to involve zinc signals, including activation of $\mathrm{T}$ cells by their $\mathrm{T}$ cell receptor and by the cytokine interleukin IL-2, the major stimulus for $\mathrm{T}$ cell proliferation once they have been activated. Furthermore, zinc signals occur in response to activation of immune cells via one type of antibodybinding receptors, so-called Fce receptors, on their surface, and after triggering of pattern recognition receptors. The latter are predominantly found on cells of the innate immune system.

Worldwide, zinc deficiency is an important public health problem affecting 2 billion people. It is estimated that a considerable proportion even of the western population is at risk of marginal zinc deficiency. Low consumption in foods rich in bioavailable zinc such as meat, particularly read meat, and high consumption of foods rich in inhibitors of zinc absorption, such as phytate, certain dietary fibers and calcium, cause zinc deficiencies [78,79]. Many of the alterations observed in zinc deficiency are considered to be important contributors to the increased susceptibility to infections, especially for children and the elderly. Already mild zinc deficiency has a negative impact on immune function, leading to recurrent infections that in turn are a cause of zinc deficiency due to zinc redistribution from plasma to intracellular sites and increased urinary losses [80]. In children, low concentrations of circulating zinc are associated with an increased risk of respiratory tract morbidity. Zinc supplementation reduces both the risk and duration of pneumonia in children and is also beneficial in the management of infantile diarrhea [10,12,81]. Zinc supplementation to maintain a normal serum concentration may help to reduce the mean incidence of infections (i.e., common cold, cold sores and flu) [81] as well as the incidence of pneumonia and associated morbidity in the elderly [82]. It has been reported that adequate zinc supply could prevent age-related diseases in the elderly such as cancer, atherosclerosis, dementia, Alzheimer's disease, etc. $[77,83,84]$.

When it comes to the common cold, zinc salts have been found to inhibit rhinovirus replication in vitro [85] and it has been suggested that zinc salts may protect plasma membranes against lysis by cytotoxic agents, such as microbial toxins and components of activated complement [86]. However, analysis of trials conducted between 1984 and 2000 investigating the role of zinc for the common cold symptoms yielded mixed results in terms of efficacy [86,87]. Inadequate treatment masking, reduced bioavailability of zinc from some formulations and overall dose have been cited as possible influencers of the results $[12,88]$.

Hemilä analyzed a subset of the Cochrane studies consisting of 13 placebo controlled trials using exclusively zinc lozenges [88]. This analysis considered both the type of zinc salts as well as the total amount of zinc used. Five of the trials used a total daily zinc dose of less than $75 \mathrm{mg}$ and uniformly found no effect. Three trials used zinc acetate in daily doses of over $75 \mathrm{mg}$ and the pooled results indicate a $42 \%$ reduction in the duration of colds. Five trials used zinc salts other than acetate in daily doses of over $75 \mathrm{mg}$ and again the pooled results show a $20 \%$ reduction in the duration of colds. Therefore, both the type of salts used and especially the dose of zinc in the lozenges impact benefits related to common cold. These findings help to explain the mixed results observed in older reviews.

The synergistic roles of vitamin C, vitamin D and zinc in immune functions are summarized in Table 1.

\begin{tabular}{|l|l|l|l|}
\hline Defense & Vitamin C & Vitamin D \\
\hline Skin and mucosal barriers & Collagen synthesis (improved strength) & $\begin{array}{l}\text { Proliferation } \\
\text { keratinocytes }\end{array}$ & $\begin{array}{l}\text { Formation of permeability barrier in the } \\
\text { skin }\end{array}$ \\
\cline { 2 - 3 } Neutrophils, Monocytes, Macrophages & $\begin{array}{l}\text { Protection of neutrophils against ROS- } \\
\text { induced damage }\end{array}$ & $\begin{array}{l}\text { Improved chemotaxis and phagocytic } \\
\text { capabilities }\end{array}$ & Deficiency impairs phagocytosis \\
\cline { 2 - 2 } & Improved motility and chemotaxis & \\
\hline
\end{tabular}




\begin{tabular}{|c|c|c|c|}
\hline & Enhanced killing & \multirow{2}{*}{$\begin{array}{l}\text { Production of antimicrobial proteins } \\
\text { (defensin } \beta 2 \text {, cathelicidin) }\end{array}$} & \\
\hline & Overall improvement of phagocytosis & & \\
\hline \multirow[t]{3}{*}{ Antigen Presenting Cells } & & Cytokine modulation & \\
\hline & & Promotion of more toleragenic state & \\
\hline & & Induction of regulatory T-cells & \\
\hline \multirow[t]{7}{*}{ B-Lymphocytes and T-lymphocytes } & \multirow[t]{7}{*}{ Proliferation } & $\begin{array}{l}\text { Control of B-cell activation and } \\
\text { proliferation, of clinical importance for } \\
\text { autoimmune diseases }\end{array}$ & Proliferation of stem cells \\
\hline & & Direct and indirect effects on T-cells & Proliferation and appropriate response \\
\hline & & $\begin{array}{l}\text { Cytokine } \\
\text { modulation }\end{array}$ & B and T-cell differentiation \\
\hline & & $\begin{array}{l}\text { Shift from pro-inflammatory to a more } \\
\text { tolerogenic status }\end{array}$ & B and T-cell interaction \\
\hline & & & Balance of Th1 and Th2 \\
\hline & & & Antibody production by B-cells \\
\hline & & & $\begin{array}{l}\text { Destruction of infected tissue cells and } \\
\text { tumors }\end{array}$ \\
\hline Interferon & Production enhanced & & \\
\hline
\end{tabular}

Table 1: Synergistic roles of vitamin C, vitamin D and zinc in body defense [2].

\section{Factors and Situations Challenging the Immune System}

Immune function is influenced by age as well genetic and a number lifestyle and environmental factors (Figure 1).

Age has an important influence on the immune system [89-91]. The fetal immune system develops in a sterile and protected environment and therefore lacks antigenic experience. It must also be modulated in order to co-exist with the mother's immune system. At birth newborns initially have an immunological milieu skewed towards Th2 immunity $[92,93]$. Soon after birth, the newborn is exposed to the "hostile world" of bacteria, viruses, fungi, and parasites, and must immediately defend itself. During this period, the newborn relies on innate systems of immune defense (evolutionary conserved and lacking memory) and passive protection (maternal colostrum and milk, maternal antibodies). The immunologic competence of the neonate progresses rapidly in the first months of life as the cells involved in acquired immunity mature and gain antigenic experience. Antigen exposure is essential to drive maturation and expansion of cells of the innate and adaptive mucosal and systemic immune system. Microbial antigens play a vital role in the education of the immune system and represent an important factor in predisposition to allergic, inflammatory and autoimmune diseases in later life [92-96]. At the other extreme of the age range, the elderly experience changes in some immune responses which can be described as a progressive occurrence of immune dysregulation leading to decreased cell-mediated immune responses while antibody responses remain relatively preserved. Seniors are more sensitive to infections than younger adults: infection is a common problem among elderly, who are 2 to 10 times more likely to die of infection than their younger counterparts. Non-specific immunity appears to be less affected by the aging process but induces a longer inflammatory process in older adults [97-99].

On the other hand, lifestyle-related factors are the main determinants of immune competence in healthy adults with a mature immune system and include in addition to diet, stress, sleeping habits, sedentary lifestyle (leading to overweight/obesity), excessive exercise (overtraining, marathon), frequent traveling (exposure to new pathogens, unbalanced diet), being in crowded spaces (e.g., while commuting in public means of transportation, or working in open space offices), temperature changes, exposure to pollution, smoking, etc. [5]. In the following, we discuss how some of these environmental factors or situations can challenge the immune system.

Crowded spaces: Confined environments and crowded places such as airplanes, trains, buses but also hospitals, schools, shopping malls, movie theaters or open space offices serve as mixers where pathogens can stay suspended and transfer from host to host thereby increasing the risk of spreading infectious diseases because close contact and long exposure increase [100-102]. When it comes to transmission mechanisms, three main ones are discussed in the medical literature: self-inoculation (through direct contact with the mucus or other bodily fluids of an infectious subject); large droplet transmission (through the spraying of infected droplets directly onto the conjunctiva or mucus of a susceptible host via coughing or sneezing) and finally airborne transmission (through inhalation of relatively small infected droplets or the pathogen-bearing solid residues of size $<5-10 \mathrm{~mm}$, that can form from the small droplets via evaporation). While the first two modes are short-range routes requiring the close proximity of individuals, the third is an indirect long-range route of transmission. Indeed, it has been reported that smaller droplets can remain 
Citation: Maggini S, Maldonado P, Cardim P, Fernandez Newball C, Sota Latino ER (2017) Vitamins C, D and Zinc: Synergistic Roles in Immune

suspended in a cough or sneeze cloud meters away from the infected person [102].

\section{Healthy immune function}

Good nutritional status

Essential micronutr ients aid in the

development, maintenance and

expression of immune response
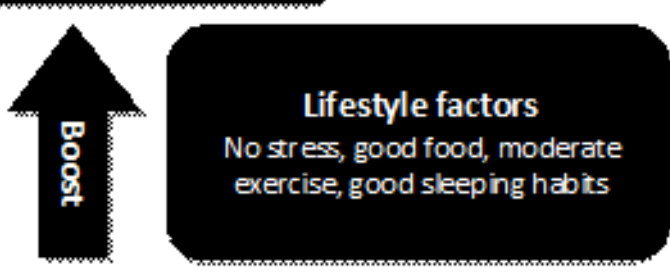

From birth: immunologic competence progresses rapidly
Undernutrition

Including deficiencies in specfic micronutrients

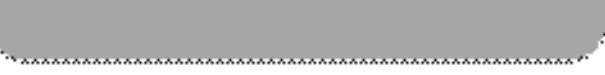

Advancing age Immune dys egulation: reduct ion in celmediated immune response, longer inflammatory process
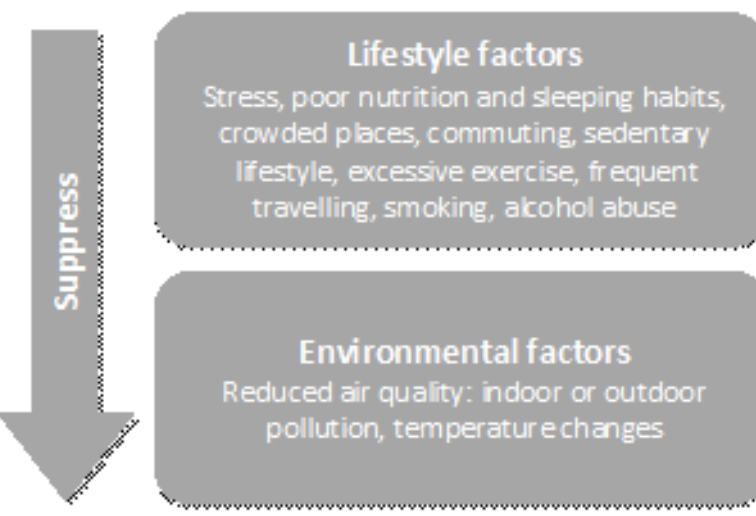

Environmental factors

Reduced air quality: indoor or outdoor pollution, temperatur echanges

Pathogenic process and modified disease risk

Figure 1: Factors affecting immune function $[2,108]$.

In the recent past, the pandemic 2009 influenza A (H1N1) spread rapidly and resulted in millions of laboratory-confirmed cases in China and other countries. After 2 Chinese provinces provided initial reports of $2009 \mathrm{H} 1 \mathrm{~N} 1$ infection in 2 persons who had travelled on the same train, Cui and et al. [101] conducted a retrospective epidemiologic investigation to collect information from the passengers, crew members, contacts, and health care providers with the aim to explore the source of infection and possible routes of transmission in the train. The authors concluded that close contact and longer time on board may have indeed contributed to the transmission of pandemic influenza H1N1 virus in the train.

As is the case with other major modes of transportation, trains play an important role in transmission of communicable disease.

A recent, well designed survey of adult passengers on 21/2 hour flights established that an average of $20 \%$ self-reported colds were experienced by these travelers when questioned 5 to 7 days after the flight [100]. This study led Hocking et al. to further analyze the data. Their analysis revealed that assuming that any air travel-related increase in cold incidence stems only from the 5 hours spent boarding, deplaning, and in the aircraft, then the transmission rate for this period is 113 times the normal daily ground level experience [100]. The analysis by Hocking and Foster [100] further revealed that recirculation of aircraft air was not a significant factor. However, reduced resistance to infection from the usual very dry cabin air and fatigue, coupled to the small cabin air space per person, and low outside air replacement rates of newer aircraft could have contributed to the very high cold transmission rates observed.

Temperature changes: Vitamin $\mathrm{C}$ has been reported to have beneficial effects on resistance and acclimatization to cold and hot environments $[8,103]$. Low temperatures weaken the immune response [8] and increase the risk of infections. Studies have reported that prolonged exposure of the body surface to cold temperatures (cold baths, cold air, wet clothes, drafts, etc.) leads to a vitamin $\mathrm{C}$ deficit [103]. Vitamin C protects against common cold caused by heavy exercise / exercise in cold (subarctic) conditions [8]. Further, chilling of the feet caused the onset of common cold symptoms in around $10 \%$ of subjects who were chilled [104]. It has also been shown that the common cold virus (rhinovirus) can reproduce itself more efficiently in the cooler temperature found inside the nose $\left(33-35^{\circ} \mathrm{C}\right)$ than at core body temperature and at the same time the immune response to the rhinovirus is impaired at the lower body temperature compared to the core body temperature [105]. Finally, a study investigating the association between diurnal temperature range and respiratory tract infections [106] reported that a diurnal temperature range increase of $1^{\circ} \mathrm{C}$ in the current-day and in the 2-day moving average corresponded 
to a $0.94 \%$ [ $95 \%$ confidence interval (CI), 0.34-1.55] and a $2.08 \%(95 \%$ CI, 1.24-2.93) increase in emergency-room visits for respiratory tract infections, respectively.

Pollution: It is well established that pollution is a global hazard to health, and a particular problem in the developing world. Unsafe water, sanitation and hygiene, indoor smoke from solid fuels, and urban outdoor air pollution rank among the top 19 risk factors worldwide contributing to disease burden and death. The mortality arising from air pollution (indoor and outdoor) is high at around 7 million premature deaths each year (i.e., 1 in every 8 deaths) and responsible for $14 \%$ of deaths globally. Diarrhea alone is responsible for $12.8 \%$ of deaths, with water pollution, sanitation and hygiene accounting for $16.4 \%$ of the disease burden globally, while lung and respiratory infections from air pollution comprise $10.7 \%$ of the global disease burden - and more than $50 \%$ in developing countries. In fact, the environmental burden per capita of diarrheal diseases and lower respiratory tract infections is $120-150$ times greater in developing vs. developed regions. Thus, reductions in air and water quality are major risk factors for disease burden and mortality $[107,108]$.

Air pollution arises from many sources, including road traffic, small-scale manufacturers, burning of biomass, coal and solid fuels for cooking and heating, coal-fired power plants, as well as tobacco consumption, volatile organic compounds, mold and pesticides. Pollution can also occur indoor and result in the so-called sick building syndrome' (SBS), where non-specific mucosal, skin and general symptoms occur, temporally related to working or living in a sick building - particularly those with poor ventilation. The symptoms of SBS include a general feeling of tiredness or lethargy, nasal congestion, dry throat and headache, for example, and often lead to reduced staff efficiency, increased absenteeism and staff turnover, extended breaks and reduced overtime, and decreased productivity. Although all of us are susceptible to the adverse effects of air pollution, certain groups have increased sensitivity, including young children with developing immune systems, the elderly who experience agerelated changes in adaptive immunity and in whom nutritional factors are extremely important, those with a poor nutrient status, smokers (increased oxidative stress and reduced vitamin C levels), office workers (particularly when emotionally vulnerable), and frequent travelers (often with poor dietary habits and at an increased risk of infection transmission) (reviewed in Haryanto et al. [108]).

One of the major underlying features of the toxic effects of air pollutants is oxidative stress, caused either by an imbalance of prooxidant and antioxidant processes linked to increased exposure to the air pollutants, or by the presence of impaired antioxidant defenses $[109,110]$. Most air pollutants are themselves free radicals (e.g., $\mathrm{NO}_{2}$, transition metals) or have the ability to initiate the production of free radicals (e.g., $\mathrm{O}_{3}$, Particulate Matter (PM)) [109,110]. They can therefore lead to oxidative stress in the lungs, participate in the induction of inflammation [111], trigger redox-sensitive signaling pathways $[109,112]$ and impair antigen presentation - making the body more susceptible to both allergic and infectious diseases [113].

An individual's sensitivity to air pollution is related in part to their endogenous pulmonary antioxidant defenses against both the primary oxidant challenge and the second wave of oxidative stress [109]. Several micronutrients play an essential role in the antioxidant defense system, either as direct antioxidants (vitamins C) or as components of antioxidant enzymes such as Superoxide Dismutase (SOD) (e.g., zinc) [114]. The synergy of endogenous and exogenous antioxidants plays a key role in the protection against the development of inflammation of the respiratory passage and aggravation of asthma and respiratory tract infections caused by air pollutants, for example [113]. Indeed, shortterm randomized supplementation trials indicate that antioxidant micronutrients can protect against the acute effect of air pollutants, particularly in vulnerable subgroups [115-117] and may reduce the occurrence of respiratory symptoms such as bronchitis, wheezing, and respiratory tract infection $[10,118,119]$.

Inadequate radiation or insufficient cutaneous absorption of Ultraviolet B (UVB) is one of the cardinal causes of vitamin D deficiency. The level of air pollution is inversely related to the extent of solar UVB that reaches the earth surface. Consequently, in polluted areas there is a reduced UVB passage which in turns lowers endogenous vitamin $\mathrm{D}$ synthesis in the skin and status. It has been reported that children in polluted areas in India were at higher risk of vitamin D deficiency and rickets [120]. Urban Belgian postmenopausal women who were exposed to higher $\mathrm{O}_{3}$ levels ( 3 times higher) but had a higher mean sun exposure index compared with rural counterparts, were found to have a higher prevalence of hypovitaminosis D [121]. Similar results were reported in healthy young women in Iran in a study demonstrating that city of residence (Tehran - high polluted area versus Ghazvin - low polluted area) and air pollution played significant independent roles in vitamin D status [122]. The authors further mentioned that aging significantly decreases the skin capacity of vitamin D synthesis in response to solar UVB, thus the role of air pollution in elderly may be more prominent than in adults or children [122]. Finally, it has been established that maternal vitamin D deficiency during pregnancy may have an influence on the development of asthma and allergic diseases in offspring. A recent study investigated the associations between gestational exposure to urban air pollutants and $25(\mathrm{OH}) \mathrm{D}$ cord blood serum level in 375 mother-child pairs [123]. Maternal exposure to ambient urban levels of $\mathrm{NO}_{2}$ and $\mathrm{PM}$ less than $10 \mu \mathrm{m}$ in diameter during the whole pregnancy was a strong predictor of low vitamin D status in newborns. This could affect the child's risk of developing diseases later in life [123].

Dietary supplementation including vitamin $C$, zinc and vitamin D may modulate the negative impact of air pollution, and boost plasma concentrations of antioxidants (known to be used to scavenge free radicals upon exposure to pollutants) or vitamin $\mathrm{D}$ (known to be reduced in polluted areas) above the normal range. Overall, this could partially attenuate the negative effects of air pollutants such as ozone and have a protective effect on the respiratory system (reviewed in Haryanto et al. [108]).

\section{Conclusion}

Vitamin C, vitamin D and zinc have immune-enhancing and immune-modulating properties and play synergistic roles in supporting components of both innate and adaptive immunity which comprise epithelial barriers, cellular defense and antibodies constituting the three main lines of immune defense. Conversely, deficiencies of vitamin $\mathrm{C}$, vitamin $\mathrm{D}$ and of zinc severely depress immune responses and lead to an increased risk for infections for example in the respiratory tract $[2,7]$.

Upper respiratory tract infections such as the common cold and influenza are among the most common illnesses in humans and, despite great advances in medicine, continue to be a great burden on society in terms of human suffering and economic losses. Micronutrient supplementation with vitamins C, D and zinc represent a possible strategy to reduce their burden. Vitamin C has consistently 
been shown to reduce the duration and severity of cold symptoms and to reduce incidence up to $50 \%$ in subjects undergoing heavy physical stress (work, sports, low temperature, etc.) [8] or in cases of marginal deficiency [35]. Zinc reduces the duration and severity of common cold symptoms in children and adults when administered in form of lozenges and taken within 24 hours of onset of symptoms [88]. A combination of $1000 \mathrm{mg}$ ascorbic acid plus $10 \mathrm{mg}$ zinc given as an effervescent tablet in subjects with common cold was found to relief some symptoms (e.g., rhinorrhea) during the first 5 days of treatment [124]. Finally, vitamin D stimulates the expression of potent antimicrobial peptides, synthesized in neutrophils, monocytes, NK cells and in epithelial cells lining the respiratory tract where they play a major role in protecting the lung from infection [40]. It's therefore not surprising that low serum $25(\mathrm{OH}) \mathrm{D}$ levels are associated with an increased risk of respiratory infections [9] and a recent meta-analysis showed a $12 \%$ decrease in the risk of acute respiratory tract infections following vitamin D supplementation [60].

Ensuring adequate levels of micronutrients such as vitamin C, D and zinc may be particularly important in situations putting an extra challenge on the immune system such as when exposed to sudden temperature changes $[8,104,105]$ or when spending time in confined spaces (e.g., airplanes, trains, buses, hospitals, schools, or open space offices) where the risk of spreading infectious diseases is high because of close contact and long exposure [100-102]. In other situations, the antioxidant properties of vitamin $\mathrm{C}$ and zinc play a critical role. One of the major underlying features of the toxic effects of air pollutants is oxidative stress, caused either by an imbalance of pro-oxidant and antioxidant processes linked to increased exposure to the air pollutants, or by the presence of impaired antioxidant defenses. Since there is an association between oxidative stress and infection, as all infections cause inflammation this will inevitably involve a degree of oxidative stress. Overall, pollution (including exposure to cigarette smoke) decreases the levels of vitamin $\mathrm{C}$ and zinc due to increased turnover increasing the needs of these micronutrients. Living in polluted areas can lead to vitamin deficiency $\mathrm{D}$ by decreasing endogenous synthesis in the skin $[108,122]$.

Multiple factors determine whether an individual will become sick or not, however the immune system remains the first line of defense against all external pathogens and other noxious insults. Like other cells and organs, also immune cells and tissues need to be fed and require adequate supply of energy, nutrients and micronutrients serving as cofactors in the development, maintenance and expression of the immune response. The evidence presented here indicates that there's a good scientific rationale for combining vitamin C, vitamin D and zinc in order to support and modulate immune functions to better realize the body's defense potential.

\section{Conflict of Interest}

All authors are employed by Bayer Consumer Health, a manufacturer of multivitamins.

\section{References}

1. Maggini S, Wintergerst ES, Beveridge S, Hornig DH (2007) Selected vitamins and trace elements support immune function by strengthening epithelial barriers and cellular and humoral immune responses. Br J Nutr 98: 29-35.

2. Maggini S (2008) Feeding the immune system: the role of micronutrients in restoring resistance to infections. CAB Reviews: Perspectives in Agriculture, Veterinary Science, Nutrition and Natural Resources 3: 98.
3. Parkin J, Cohen B (2001) An overview of the immune system. Lancet 357: 1777-1789.

4. Azad MB, Lissitsyn Y, Miller GE, Becker AB, HayGlass KT, et al. (2012) Influence of socioeconomic status trajectories on innate immune responsiveness in children. PloS One 7: 38669.

5. Calder PC, Kew S (2002) The immune system: a target for functional foods? Br J Nutr 88: S165-S177.

6. Scrimshaw NS, Taylor CE, Gordon JE (1968) Interactions of nutrition and infection. Monogr Ser World Health Organ 57: 3-329.

7. Calder PC, Jackson AA (2000) Undernutrition, infection and immune function. Nutr Res Rev 13: 3-29.

8. Hemilä H (2017) Vitamin C and infections. Nutrients 9: 339.

9. Wishart K, Maggini S, Wintergerst ES (2015) Vitamin D and immunity: Foods and Dietary Supplements in the Prevention and Treatment of Disease in Older Adults, Elsevier: 253-263.

10. Maggini S, Wenzlaff S, Hornig D (2010) Essential role of vitamin C and zinc in child immunity and health. J Int Med Res 38: 386-414.

11. Haase H, Rink L (2014) Multiple impacts of zinc on immune function. Metallomics 6: 1175-1180.

12. Wintergerst ES, Maggini S, Hornig DH (2006) Immune-enhancing role of vitamin $\mathrm{C}$ and zinc and effect on clinical conditions. Ann Nutr Metab 50: 85-94.

13. Sorice A, Guerriero E, Capone F, Colonna G, Castello G, et al. (2014) Ascorbic acid: its role in immune system and chronic inflammation diseases. Mini-Rev Med Chem 14: 444-452.

14. Thomas WR, Holt PG (1978) Vitamin C and immunity: an assessment of the evidence. Clin Exp Immunol 32: 370-379.

15. Anderson R, Oosthuizen R, Maritz R, Theron A, Van Rensburg AJ (1980) The effects of increasing weekly doses of ascorbate on certain cellular and humoral immune functions in normal volunteers. Am J Clin Nutr 33: 71-76.

16. Levine M, Conry-Cantilena C, Wang Y, Welch RW, Washko PW, et al. (1996) Vitamin C pharmacokinetics in healthy volunteers: evidence for a recommended dietary allowance. Proc Natl Acad Sci 93: 3704-3709.

17. Levine M, Dhariwal KR, Wang Y, Park JB, Welch RW (1994) Ascorbic acid in neutrophils: Natural Antioxidants in Human Health and Disease Elsevier, pp: 469-488.

18. Elste V, Troesch B, Eggersdorfer M, Weber P (2017) Emerging evidence on neutrophil motility supporting its usefulness to define Vitamin $C$ intake requirements. Nutrients 9: 503.

19. Brieger K, Schiavone S, Miller FJ, Jr., Krause KH (2012) Reactive oxygen species: from health to disease. Swiss Med Wkly 142: 13659.

20. Meydani SN, Wu D, Santos MS, Hayek MG (1995) Antioxidants and immune response in aged persons: overview of present evidence. Am J Clin Nutr 62: 1462-1476.

21. Knight JA (2000) Review: Free radicals, antioxidants, and the immune system. Ann Clin Lab Sci 30: 145-158.

22. Johnston CS, Retrum KR, Srilakshmi JC (1992) Antihistamine effects and complications of supplemental vitamin C. J Am Diet Assoc 92: 988-989.

23. Johnston CS, Martin LJ, Cai X (1992) Antihistamine effect of supplemental ascorbic acid and neutrophil chemotaxis. J Am Coll Nutr 11: $172-176$.

24. Flodin NW (1988) Vitamin C: Pharmacology of Micronutrients, Alan R. Liss, Inc., New York, pp: 201-244.

25. Bucca C, Rolla G, Farina JC (1992) Effect of vitamin C on transient increase of bronchial responsiveness in conditions affecting the airways. Ann N Y Acad Sci 669: 175-186.

26. Jariwalla RJ, Harakeh S (1996) Antiviral and Immunomodulatory activities of ascorbic acid. Subcell Biochem 25: 215-231.

27. Mortola E, Okuda M, Ohno K, Watari T, Tsujimoto H, et al. (1998) Inhibition of apoptosis and virus replication in feline immunodeficiency virus-infected cells by $\mathrm{N}$-acetylcysteine and ascorbic acid. J Vet Med Sci 60: 1187-1193. 
28. Panush RS, Delafuente JC, Katz P, Johnson J (1982) Modulation of certain immunologic responses by vitamin C. III. Potentiation of in vitro and in vivo lymphocyte responses. Int J Vitam Nutr Res Suppl 23: 35-47.

29. Anderson R, Smit MJ, Joone GK, Van Staden AM (1990) Vitamin C and cellular immune functions. Protection against hypochlorous acidmediated inactivation of glyceraldehyde-3-phosphate dehydrogenase and ATP generation in human leukocytes as a possible mechanism of ascorbate-mediated immunostimulation. Ann N Y Acad Sci 587: 34-48.

30. Haertel C, Strunk T, Bucsky P, Schultz C (2004) Effects of vitamin C on intracytoplasmic cytokine production in human whole blood monocytes and lymphocytes. Cytokine 27: 101-106.

31. Canali R, Natarelli L, Leoni G, Azzini E, Comitato R, et al. (2014) Vitamin C supplementation modulates gene expression in peripheral blood mononuclear cells specifically upon an inflammatory stimulus: a pilot study in healthy subjects. Genes Nutr 9: 390.

32. Hume R, Weyers E (1973) Changes in leucocyte ascorbic acid during the common cold. Scott Med J 18: 3-7.

33. Hemila H (1994) Does vitamin C alleviate the symptoms of the common cold?-A review of current evidence. Scand J Infect Dis 26: 1-6.

34. Hemila H, Chalker E (2013) Vitamin C for preventing and treating the common cold. Cochrane Database Syst Rev CD000980.

35. Johnston C, Barkyoumb GM, Schumacher SS (2014) Vitamin C supplementation slightly improves physical activity levels and teduces cold incidence in men with marginal vitamin $\mathrm{C}$ status: a randomized controlled trial. Nutrients 6: 2572-2583.

36. Adams JS, Liu PT, Chun R, Modlin RL, Hewison M (2007) Vitamin D in defense of the human immune response. Ann N Y Acad Sci 1117: 94-105.

37. Prietl B, Treiber G, Pieber TR, Amrein K (2013) Vitamin D and immune function. Nutrients 5: 2502-2521.

38. Gombart AF (2005) Human cathelicidin antimicrobial peptide (CAMP) gene is a direct target of the vitamin $\mathrm{D}$ receptor and is strongly upregulated in myeloid cells by 1,25-dihydroxyvitamin D3. FASEB J 19 1067-1077.

39. Ramanathan B, Davis EG, Ross CR, Blecha F (2002) Cathelicidins: microbicidal activity, mechanisms of action, and roles in innate immunity. Microbes Infect 4: 361-372.

40. Gombart AF (2009) The vitamin D-antimicrobial peptide pathway and its role in protection against infection. Future Microbiol 4: 1151-1165.

41. Rigby WF, Waugh MG (1992) Decreased Accessory Cell Function and Costimulatory Activity BY 1, 25Dihydroxyvitamin D3-Treated Monocytes. Arthritis \& Rheumatology. 35: 110-119.

42. Banchereau J, Steinman RM (1998) Dendritic cells and the control of immunity. Nature 392: 245-252.

43. Adorini L (2003) Tolerogenic dendritic cells induced by vitamin D receptor ligands enhance regulatory $\mathrm{T}$ cells inhibiting autoimmune diabetes. Ann N Y Acad Sci 987: 258-261.

44. Provvedini D, Tsoukas C, Deftos L, Manolagas S (1983) 1,25dihydroxyvitamin D3 receptors in human leukocytes. Science 221: 1181-1183.

45. Lemire JM, Adams JS, Sakai R, Jordan SC (1984) 1-alpha,25dihydroxyvitamin D3 suppresses proliferation and immunoglobulin production by normal human peripheral blood mononuclear cells. J of cClin Invest 74: 657-661.

46. Mahon BD, Wittke A, Weaver V, Cantorna MT (2003) The targets of vitamin $\mathrm{D}$ depend on the differentiation and activation status of CD4 positive T cells. J Cell Biochem 89: 922-932.

47. Chen S, Sims GP, Chen XX, Gu YY, Chen S, et al. (2007) Modulatory effects of 1,25-dihydroxyvitamin D3 on human B cell differentiation. J Immunol 179: 1634-1647.

48. Lemire JM, Adams JS, Kermani-Arab V, Bakke AC, Sakai R, et al. (1985) 1,25-Dihydroxyvitamin D3 suppresses human $\mathrm{T}$ helper/inducer lymphocyte activity in vitro. J Immunol 134: 3032-3035.

49. Wang TT, Nestel FP, Bourdeau V, Nagai Y, Wang Q, et al. (2004) Cutting edge: 1,25-dihydroxyvitamin D 3 Is a direct inducer of antimicrobial peptide gene expression. J Immunol 173: 2909-2912.
50. Liu PT, Stenger S, Wenzel L, Tan BH, Krutzik SR, et al. (2006) Toll-like receptor triggering of a vitamin D-mediated human antimicrobial response. Science 311: 1770-1773.

51. Science M, Maguire JL, Russell ML, Smieja M, Walter SD, et al. (2013) Low serum 25-hydroxyvitamin D level and risk of upper respiratory tract infection in children and adolescents. Clin Infect Dis 57: 392-397.

52. Holick MF (2007) Vitamin D deficiency. N Engl J Med 357: 266-281.

53. Sundaram ME, Coleman LA (2012) Vitamin D and influenza. Adv Nutr 3 : $517-525$.

54. Cannell JJ, Vieth R, Umhau JC, Holick MF, Grant WB, et al. (2006) Epidemic influenza and vitamin D. Epidemiol Infect 134: 1129-1140.

55. Ginde AA, Mansbach JM, Camargo CA (2009) Association between serum 25-hydroxyvitamin $\mathrm{D}$ level and upper respiratory tract infection in the third national health and nutrition examination survey. Arch Intern Med 169: 384-390.

56. Murdoch DR, Slow S, Chambers ST, Jennings LC, Stewart AW, et al. (2012) Effect of vitamin D3 supplementation on upper respiratory tract infections in healthy adults. JAMA 308: 1333-1339.

57. Yamshchikov AV, Desai NS, Blumberg HM, Ziegler TR, Tangpricha V (2009) Vitamin D for treatment and prevention of infectious diseases: a systematic review of randomized controlled trials. Endoc Pract 15: 438-449.

58. Charan J, Goyal JP, Saxena D, Yadav P (2012) Vitamin D for prevention of respiratory tract infections: A systematic review and meta-analysis. J Pharmacol Pharmacother 3: 300-303

59. Bergman P, Lindh ÅU, Björkhem-Bergman L, Lindh JD (2013) Vitamin D and respiratory tract infections: a systematic review and meta-analysis of randomized controlled trials. PloS One 8: e65835.

60. Martineau AR, Jolliffe DA, Hooper RL, Greenberg L, Aloia JF, et al. (2016) Vitamin D supplementation to prevent acute respiratory infections: systematic review and meta-analysis of individual participant data. Thorax 71: A60.62-A61.

61. Haase H, Rink L (2007) Signal transduction in monocytes: the role of zinc ions. Biometals 20: 579-585.

62. Rink L, Haase H (2007) Zinc homeostasis and immunity. Trends in immunology 28: 1-4.

63. Overbeck S, Rink L, Haase $\mathrm{H}$ (2008) Modulating the immune response by oral zinc supplementation: a single approach for multiple diseases. Arch Immunol Ther Exp 56: 15-30.

64. Tapiero H, Tew KD (2003) Trace elements in human physiology and pathology: zinc and metallothioneins. Biomed Pharmacother 57: 399-411.

65. Keen CL, Gershwin ME (1990) Zinc deficiency and immune function. Annu Rev Nutr 10: 415-431.

66. Prasad AS (2000) Effects of zinc deficiency on immune functions. The Journal of Trace Elements in Experimental Medicine 13: 1-20.

67. Ravaglia G, Forti P, Maioli F, Bastagli L, Facchini A, et al. (2000) Effect of micronutrient status on natural killer cell immune function in healthy free-living subjects aged $\geq 90$ y1,2,3. Am J Clin Nutr 71: 590-598.

68. Allen JI, Perri RT, McClain CJ, Kay NE (1983) Alterations in human natural killer cell activity and monocyte cytotoxicity induced by zinc deficiency. J Lab Clin Med 102: 577-589.

69. Wellinghausen N, Kirchner H, Rink L (1997) The immunobiology of zinc. Immunol Today 18: 519-521.

70. Fraker PJ, Haas SM, Luecke RW (1977) Effect of zinc deficiency on the immune response of the young adult A/J mouse. J Nutr 107: 1889-1895.

71. Fraker PJ, DePasquale-Jardieu P, Zwickl CM, Luecke RW (1978) Regeneration of T-cell helper function in zinc-deficient adult mice. Proc Natl Acad Sci 75: 5660-5664.

72. Dardenne M, Pleau JM, Nabarra B, Lefrancier P, Derrien M, et al. (1982) Contribution of zinc and other metals to the biological activity of the serum thymic factor. Proc Natl Acad Sci 79: 5370-5373.

73. Bach JF, Dardenne M (1989) Thymulin, a zinc-dependent hormone. Med Oncol Tumor Pharmacother 6: 25-29. 
74. Prasad AS (2000) Effects of zinc deficiency on Th1 and Th2 cytokine shifts. J Infect Dis 182: S62-S68.

75. Beck FW, Prasad AS, Kaplan J, Fitzgerald JT, Brewer GJ (1997) Changes in cytokine production and $\mathrm{T}$ cell subpopulations in experimentally induced zinc-deficient humans. Am J Physiol 272: 1002-1007.

76. Prasad AS (1998) Zinc and immunity. Mol Cell Biochem 188: 63-69.

77. Stefanidou M, Maravelias C, Dona A, Spiliopoulou C (2006) Zinc: a multipurpose trace element. Arch Toxicol 80: 1-9.

78. Tuerk MJ, Fazel N (2009) Zinc deficiency. Curr Opin Gastroenterol 25: 136-143.

79. Brown KH, Rivera JA, Bhutta Z, Gibson RS, et al. (2004) Technical document \#1. Assessment of the risk of zinc deficiency in populations and options for its control. Food Nutr Bull 25: S91-203.

80. Livingstone C (2015) Zinc. Nutr Clin Pract 30: 371-382.

81. Prasad AS (2007) Zinc: mechanisms of host defense. J Nutr 137: 1345-1349.

82. Meydani SN, Barnett JB, Dallal GE, Fine BC, Jacques PF, et al. (2007) Serum zinc and pneumonia in nursing home elderly. Am J Clin Nutr 86: 1167-1173.

83. Mocchegiani E (2007) Zinc and ageing: third Zincage conference. Immun Ageing 4: 1-5.

84. Mocchegiani E, Giacconi R, Cipriano C, Costarelli L, Muti E, et al. (2007) Zinc, metallothioneins, and longevity: effect of zinc supplementation: zincage study. Ann N Y Acad Sci 1119: 129-146.

85. Korant BD, Kauer JC, Butterworth BE (1974) Zinc ions inhibit replication of rhinoviruses. Nature 248: 588-590.

86. Jackson EA (2000) Are zinc acetate lozenges effective in decreasing the duration of symptoms of the common cold? J Fam Pract 49: 1153.

87. Marshall I (1999) Zinc for the common cold: Cochrane Database of Systematic Reviews, John Wiley \& Sons, Ltd.

88. Hemilä H (2011) Zinc lozenges may shorten the duration of colds: a systematic review. Open Resipr Med J 5: 51-58.

89. Albers R, Antoine JM, Bourdet-Sicard R, Calder PC, Gleeson M, et al (2005) Markers to measure immunomodulation in human nutrition intervention studies. Br J Nutr 94: 452-481.

90. Knight JA (2001) The biochemistry of aging. Adv Clin Chem 35: 1-62.

91. Chandra RK (2002) Nutrition and the immune system from birth to old age. Eur J Clin Nutr 56: S73-S76.

92. Calder PC, Krauss-Etschmann S, de Jong EC, Dupont C, Frick JS, et al. (2006) Early nutrition and immunity - progress and perspectives. Br J Nutr 96: 774-790.

93. Morein B, Blomqvist G, Hu K (2007) Immune responsiveness in the neonatal period. J Comp Pathol 137: 27-31.

94. West LJ (2002) Defining critical windows in the development of the human immune system. Hum Exp Toxicol 21: 499-505.

95. Jónsdóttir I (2007) Maturation of mucosal immune responses and influence of maternal antibodies. J Comp Pathol 137: S20-S26.

96. Levy O (2007) Innate immunity of the newborn: basic mechanisms and clinical correlates. Nat Rev Immunol 7: 379-390.

97. Lesourd B (1999) Immune response during disease and recovery in the elderly. Proc Nutr Soc 58: 85-98.

98. Lesourd B, Mazari L (1999) Nutrition and immunity in the elderly. Proc Nutr Soc 58: 685-695.

99. Castle SC (2000) Clinical relevance of age-related immune dysfunction. Clin Infect Dis 31: 578-585.

100. Hocking MB, Foster HD (2004) Common cold transmission in commercial aircraft: Industry and passenger implications. J Environ Health Res 3: 7-12.

101. Cui F, Luo H, Zhou L, Yin D, Zheng C, et al. (2011) Transmission of pandemic influenza A (H1N1) virus in a train in China. J Epidemiol 21: 271-277.
102. Bourouiba L, Dehandschoewercker E, Bush John WM (2014) Violent expiratory events: on coughing and sneezing. J Fluid Mech 745: 537-563.

103. Dugal LP (1961) Vitamin C in relation to cold temperature tolerance. Ann N Y Acad Sci 92: 307-317.

104. Johnson C, Eccles R (2005) Acute cooling of the feet and the onset of common cold symptoms. Fam Pract 22: 608-613.

105. Foxman EF, Storer JA, Fitzgerald ME, Wasik BR, Hou L, et al. (2015) Temperature-dependent innate defense against the common cold virus limits viral replication at warm temperature in mouse airway cells. Proc Natl Acad Sci 112: 827-832.

106. Ge WZ, Xu F, Zhao ZH, Zhao JZ, Kan HD (2013) Association between diurnal temperature range and respiratory tract infections. Biomed Environ Sci 26: 222-225.

107. Kuehn BM (2014) WHO: more than 7 million air pollution deaths each year. JAMA 311: 1486

108. Haryanto B, Suksmasari T, Wintergerst E, Maggini S (2015) Multivitamin supplementation supports immune function and ameliorates conditions triggered by reduced air quality. Vitam Miner 3:128.

109. Kelly FJ, Dunster C, Mudway I (2003) Air pollution and the elderly: oxidant/antioxidant issues worth consideration. Eur Respir J 21: 70-75.

110. Delfino RJ, Staimer N, Vaziri ND (2011) Air pollution and circulating biomarkers of oxidative stress. Air Qual Atmos Health 4: 37-52.

111. Apte JS, Bombrun E, Marshall JD, Nazaroff WW (2012) Global intraurban intake fractions for primary air pollutants from vehicles and other distributed sources. Env Sci Technol 46: 3415-3423.

112. Lodovici M, Bigagli E (2011) Oxidative stress and air pollution exposure. J Toxicol 2011: 1-9.

113. Majkowska-Wojciechowska B, Kowalski ML (2012) Allergens, air pollutants and immune system function in the era of global warming. Air Pollution - Monitoring, Modelling, Health and Control. InTech pp: 1-35.

114. Evans P, Halliwell B (2001) Micronutrients: oxidant/antioxidant status. $\mathrm{Br}$ J Nutr 85: 67-74

115. Grievink L, Smit HA, Brunekreef B (2000) Anti-oxidants and air pollution in relation to indicators of asthma and COPD: a review of the current evidence. Clinical Experimental Allergy 30: 1344-1354.

116. Romieu I, Sienra-Monge JJ, Ramírez-Aguilar M, Téllez-Rojo MM, Moreno-Macías H, et al. (2002) Antioxidant supplementation and lung functions among children with asthma exposed to high levels of air pollutants. Amer J Resp Crit Care 166: 703-709.

117. Romieu I, Téllez-Rojo MM, Lazo M, Manzano-Patiño A, Cortez-Lugo M, et al. (2005) Omega-3 fatty acid prevents heart rate variability reductions associated with particulate matter. Amer J Resp Crit Care 172: 1534-1540.

118. Peters EM, Goetzsche JM, Grobbelaar B, Noakes TD (1993) Vitamin C supplementation reduces the incidence of postrace symptoms of upperrespiratory-tract infection in ultramarathon runners. Am J Clin Nutr 57: 170-174.

119. Sauberlich HE (1994) Pharmacology of vitamin C. Annu Rev Nutr 14: 371-391

120. Agarwal KS (2002) The impact of atmospheric pollution on vitamin D status of infants and toddlers in Delhi, India. Arch Dis Child 87: 111-113.

121. Manicourt DH, Devogelaer JP (2008) Urban tropospheric ozone increases the prevalence of vitamin D deficiency among Belgian postmenopausal women with outdoor activities during summer. J Clin Endocrinol Metab 93: 3893-3899.

122. Hosseinpanah F, pour SH, Heibatollahi M, Moghbel N, Asefzade S, et al. (2010) The effects of air pollution on vitamin D status in healthy women: a cross sectional study. BMC Public Health 10: 519.

123. Baïz N, Dargent-Molina P, Wark JD, Souberbielle J-C, Slama R, et al. (2012) Gestational exposure to urban air pollution related to a decrease in cord blood vitamin D levels. J Clin Endocrinol Metab 97: 4087-4095.

124. Maggini S, Beveridge S, Suter M (2012) A combination of high-dose vitamin C plus zinc for the common cold. J Int Med Res 40: 28-42. 